\title{
First report of Wiwaxia from the Cambrian Chengjiang Lagerstätte
}

\begin{tabular}{|r|l|}
\hline Journal: & Geological Magazine \\
\hline Manuscript ID: & GEO-14-1196.R1 \\
\hline Manuscript Type: & Rapid Communication \\
\hline Complete List of Authors: & $\begin{array}{l}\text { Zhao, Fangchen; Nanjing Institute of Geology and Palaeontology, Chinese } \\
\text { Academy of Sciences, } \\
\text { Smith, Martin R.; University of Cambridge, Department of Earth Sciences } \\
\text { Yin, Zongjun; Nanjing Institute of Geology and Palaeontology, State Key } \\
\text { Laboratory of Palaeobiology and Stratigraphy } \\
\text { Zeng, Han; Nanjing Institute of Geology and Palaeontology, State Key } \\
\text { Laboratory of Palaeobiology and Stratigraphy } \\
\text { Hu, Shixue; Chengdu Center of China Geological Survey, Chengdu Institute } \\
\text { of Geology and Mineral Resources } \\
\text { Li, Guoxiang; Nanjing Institute of Geology and Palaeontology, State Key } \\
\text { Laboratory of Palaeobiology and Stratigraphy } \\
\text { Zhu, Maoyan; Chinese Academy of Sciences, Nanjing Institute of Geology } \\
\text { and Palaeontology }\end{array}$ \\
\hline Keywords: & $\begin{array}{l}\text { Maotianshan shale, Cambrian Series 2, Mollusca, halwaxiids, Cambrian } \\
\text { explosion, China }\end{array}$ \\
\hline
\end{tabular}


First report of Wiwaxia from the Cambrian Chengjiang Lagerstätte

FANG-CHEN ZHAO *†, MARTIN R. SMITH $\ddagger$, ZONG-JUN YIN *, HAN ZENG *, SHI-XUE HU §, GUO-XIANG LI * \& MAO-YAN ZHU *

* State Key Laboratory of Palaeobiology and Stratigraphy, Nanjing Institute of Geology and Palaeontology, Chinese Academy of Sciences, 39 East Beijing Road, Nanjing 210008, China;

\$ Department of Earth Sciences, University of Cambridge, Cambridge, CB2 3EQ, UK.

$\S$ Chengdu Institute of Geology and Mineral Resources, Chengdu Center of China Geological Survey, Chengdu 610081, China.

†Author for correspondence: fczhao@nigpas.ac.cn

\begin{abstract}
The robust spines and sclerites of the early to middle Cambrian 'mollusc' Wiwaxia are ubiquitous in suitably-preserved deposits - but are strikingly absent from the Chengjiang Lagerstätten (Cambrian Stage 3, Yunnan Province, southwest China). Here we provide the first record of Wiwaxia sclerites from this rich deposit, extending the record of the genus to earliest Cambrian Series 2. This reinforces the cosmopolitan distribution of this iconic Cambrian lophotrochozoan and demonstrates the strong faunal continuity that unites distant Cambrian Lagerstätten.
\end{abstract}


Keywords: Maotianshan shale, Mollusca, halwaxiids, Cambrian explosion, China

\section{Introduction}

Since the first discovery of its isolated sclerites (Matthew, 1899), Wiwaxia has established itself among the iconic Burgess Shale problematica. Until recently, its affinity was considered unresolvable (Eibye-Jacobsen, 2004); an interpretation as a mollusc - whether at a crown-group or stem-group level (Scheltema \& Ivanov 2002; Scheltema et al. 2003; Caron et al. 2006, 2007; Conway Morris \& Caron, 2007) had competed with alternative positions in the annelid crown group or stem group (Walcott, 1911; Butterfield, 1990, 2003, 2006, 2008; Conway Morris \& Peel, 1995), or in the stem group to Annelida + Brachiopoda (Conway Morris \& Caron, 2007). Membership of an extinct phylum with remote affiliation to the molluscs had also been proposed (Bengtson \& Conway Morris, 1984; Conway Morris, 1985). A position among Mollusca was finally established through the identification of radula-like mouthparts, a creeping ventral foot and an Aculiferan-like scleritome - even if Wiwaxia's exact position within the molluscs remains unresolved (Smith, 2012, 2014).

Despite the phylogenetic uncertainty, the morphology of Wiwaxia's dorsal imbricating scleritome is well constrained by hundreds of articulated specimens from the Burgess Shale (Walcott, 1911; Conway Morris, 1985; Smith, 2012, 2014), complemented by a handful of further individuals from Utah (Conway Morris et al. in press) and two localities in South China (Sun et al. 2014; Yang et al. 2014). The Wiwaxia scleritome comprised eight rows of overlapping scale-like sclerites, 
punctuated (in adults) by two rows of elongate dorsal spines. Sclerites are arranged in four distinct zones on either side of the body (ventral, lower lateral, upper lateral and dorsal), with a distinct zone of sclerites arming the anterior of the body. Leaf-like, the sclerites comprise a smooth proximal root that opens out into an oval, siculate or spinose blade; this blade has a reinforced margin and edge-parallel ribs, and sometimes bears a pustular ornament (Butterfield \& Harvey, 2012; Smith, 2014). Elongate internal chambers indicate that they were secreted by microvilli, suggesting a chitinous original composition (Butterfield, 1990; Smith, 2014). This recalcitrant carbonaceous construction gives the sclerites a strong preservation potential in suitable taphonomic regimes, either as Burgess Shale-type macrofossils or as robust acid-extracted microfossils (Small Carbonaceous Fossils, see Butterfield and Harvey 2012).

The distinctive shape and robust constitution of Wiwaxia sclerites has led to their recognition in a worldwide suite of deposits representing platform to outer shelf environments from Cambrian Series 2 to 3 (Fig. 1; Conway Morris, 1985; Butterfield, 1994; Zhao et al. 1994; Ivantsov et al. 2005; Fatka et al. 2011; Sun et al. 2014; Yang et al. 2014). Thus, although articulated specimens are only known from four sites (Conway Morris 1985; Zhao et al. 1994; Sun et al. 2014; Yang et al. 2014; Conway Morris et al. in press), isolated sclerites extend the range of Wiwaxia to North America (Mount Cap, Stephen, Earlie, Pika, Spence Formation; Matthew, 1899; Walcott, 1911; Conway Morris, 1985; Conway Morris \& Robison, 1988; Butterfield, 1994; Harvey \& Butterfield, 2011; Butterfield \& Harvey, 2012), South China 
(Tsinghsutung, Kaili Formation; Zhao et al. 1994, 1999; Harvey et al. 2012; Sun et al. 2014), Australia (Emu Bay Shale, Monastery Creek Formation; Porter, 2004), Siberia

(Sinsk Formation; Ivantsov et al. 2005), and the Czech Republic (Buchava Formation; Fatka et al. 2011). Nevertheless, Wiwaxia has not been reported from Chengjiang, even though this is among the richest and best sampled Cambrian Lagerstätten (Zhao et al. 2012, 2014) and has a broadly equivalent ecological and taxonomic composition to the Burgess Shale biota, where Wiwaxia is known from hundreds of specimens (Conway Morris, 1985; Smith, 2014). Here, we fill this surprising gap in Wiwaxia's distribution with a report of associated sclerites from Chengjiang.

\section{Materials and methods}

Our material was collected from the mudstone-dominated Maotianshan Shale Member of the Yu'anshan Formation, Cambrian Series 2, Stage 3, Eoredlichia-Wudingaspis Zone (Chen et al. 1996; Zhu et al. 2001), at the Mafang section, Haikou, Yunnan, southwest China $\left(24^{\circ} 46^{\prime} 20^{\prime \prime} \mathrm{N}, 102^{\circ} 35^{\prime} 10^{\prime \prime}\right.$ E). Detailed locality information and fossil taphofacies were presented by Zhao et al. (2009). The material was prepared using a blade and is deposited in the Nanjing Institute of Geology and Palaeontology, Chinese Academy of Sciences, China (NIGPAS). Photographs were taken under dark field illumination using a Zeiss Discovery V20 microscope system.

\section{Description}

The material consists of part and counterpart of a single slab of fine-grained mudstone 
(NIGPAS160801a/b) preserving compressions of four aligned bundles of sclerites on a single bedding surface (Fig. 2). It exhibits characteristic Chengjiang-type preservation (Zhu et al. 2005); its originally carbonaceous components are reflected by weathered aluminosilicate films associated with superficial iron oxides.

The sclerite bundles contain one to four sclerites of similar size, around $8 \mathrm{~mm}$ long and 0.8-1.6 $\mathrm{mm}$ wide; sclerites within a bundle are closely aligned such that their tips and bases are almost adjacent. Sclerites appear to vary in curvature and width between bundles, with the aspect ratio varying from 6:1 to approximately 10:1. This apparent variation may reflect differences in the obliquity of the sclerites' burial angle, or result from post-mortem deformation. Each sclerite proceeds from a narrow root to a gently curved blade that tapers to a pointed apex with an angle of $\sim 20^{\circ}$. Longitudinal ribs adorn the blade, although these are difficult to distinguish from sclerite margins. Individual sclerites can only be discriminated by identifying their tips: four sclerites are evident in the first bundle, four in the second, one in the third, and four in the fourth. These counts may represent underestimates; sclerites with occluded tips cannot be identified, and if additional sclerites exist, their margins are difficult to distinguish from ribs.

The identity of this material as Wiwaxia sclerites is indicated by the sclerites' outlines, longitudinal ribbing, smooth root, and limited three dimensional relief (indicating an originally robust carbonaceous composition). Their close association indicates that they were linked by connective tissue (presumably decayed) when they 
were buried.

The parallel preservation of multiple bundles recalls a transverse row of sclerites (cf. Smith, 2014, fig. 5B). Under this interpretation, the four bundles correspond to the four zones of body sclerites. However, the absence of the fan-like splaying typically associated with non-ventral sclerites (e.g. Fig. 2e) militates against this interpretation, as do the extreme difference between the length:width ratio of the second and third bundle of sclerites (c. 8) and the smaller values in the non-ventral sclerites of $W$. corrugata $(1.8 \pm 0.5)$ and $W$. foliosa (1.82 \pm 0.3) (Fig. 3a). (Detailed measurements from $W$. herka are not available.)

More promisingly, the fossil might correspond to iterated bundles of ventral sclerites. This interpretation accounts for the curvature present in all sclerites, the regular spacing of the four bundles, each bundle's limited splaying. The length:width ratio of each bundle fits the profile of the ventral sclerites of W. corrugata and (assuming a similar trend with increasing sclerite size) W. foliosa (Fig. 3b), the latter species being only currently known from diminutive (juvenile?) specimens. (Due to oblique preservation, particularly in the first two sclerite bundles, measurements of sclerite width are likely underestimates.) We therefore interpret our material as an articulated series of ventral Wiwaxia sclerites of indeterminate species.

\section{Discussion}

This is the first report of Wiwaxia from the Chengjiang biota, representing the earliest 
record of the taxon and further expanding its broad geographical range. Its apparent absence from the Chengjiang deposits was a long-standing puzzle, particularly given its prominence in multiple Burgess Shale-type through the Cambrian and the relatively high preservation potential of Wiwaxia sclerites in Burgess Shale-type biotas (Butterfield \& Harvey, 2012). Evolution, biostratigraphy and ecology had been cited to account for its absence (Butterfield, 2003). We can now show that Wiwaxia had evolved and was present in the Chengjiang region by Cambrian Stage 3, adding it to a growing roster of species that were once considered endemic but are now recognized in both Lagerstätten: taxa such as Primicaris and Misszhouia, previously unique to Chengjiang, have recently been described in the Burgess Shale (Caron et al. 2014), whereas taxa such as Nectocaris have been identified in Chengjiang after being considered unique to the Burgess Shale (Smith, 2013).

Wiwaxia nevertheless remains a rare component of the Chengjiang faunaparticularly in view of the $c .500$ articulated specimens known from the Burgess Shale (Smith, 2014). Ecology and taphonomy account for this discrepancy; the Chengjiang deposits represent the relatively shallow-water settings of the continental platform (Zhang et al. 2008), whereas the majority of Burgess Shale sites sample a basinal setting representing deeper waters off the platform edge (Caron et al. 2010, 2014). What is more, substantial differences characterize contemporary Burgess Shale communities that are separated by trivial spatial and stratigraphic distances (Caron et al. 2010, 2014), emphasizing the prominent role of local-scale factors in controlling community composition. As such, Wiwaxia represents a striking example 
of faunal continuity between these two Lagerstätten, despite distinct environmental settings, a time difference of some 15 million years, and substantial geographic separation.

Acknowledgements. Research was supported by the Chinese Academy of Sciences (KZZD-EW-02-2); the National Basic Research Program of China (2013CB835006); the National Natural Science Foundation of China (41472012); the Natural Science Foundation of Jiangsu Province (BK2012893); and Clare College, Cambridge. We thank the anonymous reviewers for their constructive comments and improving the manuscript.

Figure 1. Distribution of Wiwaxia. (a) Stratigraphic distribution. (b) Palaeogeographic distribution (modified after McKerrow et al. 1992; Álvaro et al. 2003; Fatka et al. 2011). Numbers in (a) correspond to those plotted in (b).

Figure 2. Sclerites of Wiwaxia. (a-d) from the lower Cambrian (Series 2, Stage 3) Maotianshan Shale Member, Yu'anshan Formation (Eoredlichia-Wudingaspis Zone) in the Mafang section, Haikou near Kunming, Yunnan Province; (e) from the middle Cambrian (Series 3, Stage 5) Burgess Shale. (a) Part (NIGPAS160801a). (b) Enlargement of boxed area, showing tips of constituent 
sclerites in third bundle. (c) Counterpart (NIGPAS160801b). (d) Interpretative sketch of counterpart. (e) Semi-articulated scleritome from the Burgess Shale (Royal Ontario Museum 56965) illustrating variation in morphology between sclerite zones and splayed habit of upper lateral sclerite zone.

Figure 3. Comparison of sclerites from Chengjiang with those of other Wiwaxia species. Aspect ratio of sclerites in first (1), second (2), third (3) and fourth (4) sclerite bundles in NIGPAS160801 compared to non-ventral (a) and ventral (b) sclerites of Wiwaxia corrugata (c, blue) and $W$. foliosa (f, orange). Width measurements from NIGPAS160801 may represent underestimates due to oblique preservation (see text).

\section{References}

Álvaro, J. J., Elicki, O., Geyer, G., Rushton, A. W. A. \& Shergold, J.H. 2003. Palaeogeographical controls on the Cambrian trilobite immigration and evolutionary patterns reported in the western Gondwana margin. Palaeogeography, Palaeoclimatology, Palaeoecology 195, 5-35.

Bengston, S. \& Conway Morris, S. 1984. A comparative study of Lower Cambrian Halkieria and Middle Cambrian Wiwaxia. Lethaia 17, 307-29.

Butterfield, N. J. 1990. A reassessment of the enigmatic Burgess Shale fossil Wiwaxia corrugata (Matthew) and its relationship to the polychaete Canadia spinosa Walcott. Paleobiology 16, 287-303.

Butterfield, N. J. 1994. Burgess Shale-type fossils from a Lower Cambrian 
shallow-shelf sequence in northwestern Canada. Nature 369, 477-9.

Butterfield, N. J. 2003. Exceptional fossil preservation and the Cambrian Explosion. Integrative and Comparative Biology 43,166-77.

BUtTERFIELD, N. J. 2006. Hooking some stem-group “worms”: fossil lophotrochozoans in the Burgess Shale. BioEssays 28, 1161-6.

Butterfield, N. J. 2008. An early Cambrian radula. Journal of Paleontology 82(3), 543-54.

Butterfield, N. J. \& Harvey, T. H. P. 2012. Small Carbonaceous Fossils (SCFs): a new measure of early Paleozoic paleobiology. Geology 40, 71-4.

Caron, J.-B., Scheltema, A. H., Schander, C. \& Rudkin, D. 2006. A soft-bodied mollusc with radula from the Middle Cambrian Burgess Shale. Nature 442, $159-63$.

Caron, J.-B., Scheltema, A. H., Schander, C., \& Rudkin, D. 2007. Reply to Butterfield on stem-group "worms": fossil lophotrochozoans in the Burgess Shale. BioEssays 29, 200-2.

Caron, J.-B., Gaines, R. R., Mángano, M. G., Streng, M. \& Daley, A. C. 2010. A new Burgess Shale-type assemblage from the "thin" Stephen Formation of the southern Canadian Rockies. Geology 38, 811-4.

Caron, J.-B., Gaines, R. R., Aria, C., Mángano, M. G. \& Streng, M. 2014. A new phyllopod bed-like assemblage from the Burgess Shale of the Canadian Rockies. Nature Communications 5, 3210. doi:10.1038/ncomms4210.

Chen, J. Y., Zhou, G. Q., Zhu, M. Y. \& YeH, K. 1996. The Chengjiang Biota-A 
Unique Window of the Cambrian Explosion. The National Museum of Natural Science, Taichung, 222pp. [in Chinese].

Conway Morris, S. 1985. The Middle Cambrian metazoan Wiwaxia corrugata

(Matthew) from the Burgess Shale and Ogygopsis Shale, British Columbia, Canada. Philosophical Transactions of the Royal Society of London, Series B 307, 507-82.

Conway Morris, S. \& CARon, J.-B. 2007. Halwaxiids and the early evolution of the lophotrochozoans. Science 315, 1255-8.

Conway Morris, S. \& Peel, J. S. 1995. Articulated halkieriids from the Lower Cambrian of North Greenland and their role in early protostome evolution. Philosophical Transactions of the Royal Society of London, Series B 347, $305-58$

Conway Morris, S. \& Robison, R. A. 1988. More soft-bodied animals and algae from the Middle Cambrian of Utah and British Columbia. The University of Kansas Paleontological Contribution 122, 23-84.

Conway Morris, S., Selden, P. A., Gunther, G., Jamison, P. M. \& Robison, R. A. New records of Burgess Shale-type taxa from the middle Cambrian of Utah. Journal of Paleontology [in press].

EIBYe-JACOBSEN, D. 2004. A reevaluation of Wiwaxia and the polychaetes of the Burgess Shale. Lethaia 37(3), 317-35.

FAtKa, O., Kraft, P. \& Szabad, M. 2011. Shallow-water occurrence of Wiwaxia in the Middle Cambrian of the Barrandian area (Czech Republic). Acta 
Palaeontologica Polonica 56, 871-5.

Harvey, T. H. P. \& ButTerfield, N. J. 2011. Macro- and microfossils of the Mount Cap Formation (Early and Middle Cambrian, Northwest Territories). Geoscience Canada 38, 165-73.

Harvey, T. H. P., Ortega-Hernández, J., Lin, J. P., ZhaO, Y. L. \& Butterfield, N. J. 2012. Burgess Shale-type microfossils from the middle Cambrian Kaili Formation, Guizhou Province, China. Acta Palaeontologica Polonica 57, 423-36.

Ivantsov, A. Y., Zhuravlev, A. Y. \& Leguta, A. V. 2005. Palaeoecology of the Early Cambrian Sinsk biota from the Siberian Platform. Palaeogeography, Palaeoclimatology, Palaeoecology 220, 69-88.

Matthew, G. F. 1899. Studies on Cambrian Faunas, No. 3. Upper Cambrian fauna, Mount Stephen, British Columbia. The trilobites and worms. Transactions of the Royal Society of Canada 5, 39-66.

Mckerrow, W. S., Scotese, C. R., \& Brasier, M. D. 1992. Early Cambrian continental reconstructions. Journal of Geological Society London 149, 599-606.

Porter, S. M. 2004. Halkieriids in Middle Cambrian phosphatic limestones from Australia. Journal of Paleontology 78, 574-90.

Scheltema, A. H., \& Ivanov, D. L. 2002. An aplacophoran postlarva with iterated dorsal groups of spicules and skeletal similarities to Paleozoic fossils. Invertebrate Biology 121, 1-10. 
Scheltema, A. H., Kerth, K. \& Kuzirian, A. M. 2003. Original molluscan radula:

Comparisons among Aplacophora, Polyplacophora, Gastropoda, and the Cambrian fossil Wiwaxia corrugata. Journal of Morphology 257(2), 219-45.

SMITH, M. R. 2012. Mouthparts of the Burgess Shale fossils Odontogriphus and Wiwaxia: implications for the ancestral molluscan radula. Proceedings of the Royal Society of London, Series B 279, 4287-95.

SMITH, M. R. 2013. Nectocaridid ecology, diversity and affinity: early origin of a cephalopod-like body plan. Paleobiology 39, 297-321.

SMith, M. R. 2014. Ontogeny, morphology and taxonomy of the soft-bodied Cambrian "mollusc" Wiwaxia. Palaeontology 57, 215-29.

Sun, H. J., ZhaO, Y. L., Peng, J. \& YANG, Y. N. 2014. New Wiwaxia material from the Tsinghsutung Formation (Cambrian Series 2) of Eastern Guizhou, China. Geological Magazine 151, 339-48.

Walcott, C. D. 1911. Middle Cambrian annelids. Smithsonian Miscellaneous Collections 57(2), 109-44.

YANG, J., Smith, M. R., LAN, T., Hou, J. B. \& Zhang, X. G. 2014. Articulated Wiwaxia from the Cambrian Stage 3 Xiaoshiba Lagerstätte. Scientific Reports 4, 4643. doi:10.1038/srep04643.

Zhang, X. L., LiU, W. \& ZhaO, Y. L. 2008. Cambrian Burgess Shale-type Lagerstätten in South China: distribution and significance. Gondwana Research 14, 255-62.

Zhao, F. C., Caron, J.-B., Hu, S. X. \& Zhu. M. Y. 2009. Quantitative analysis of 
taphofacies and paleocommunities in the early Cambrian Chengjiang Lagerstätte. Palaios 24, 826-39.

Zhao, F. C., Hu, S. X., Caron, J.-B., ZhU, M. Y., Yin, Z. J. \& Lu. M. 2012. Spatial variation in the diversity and composition of the Lower Cambrian (Series 2, Stage 3) Chengjiang biota, southwest China. Palaeogeography, Palaeoclimatology, Palaeoecology 346-347, 54-65.

Zhao, F. C., Caron, J.-B., Bottuer, D. J., Hu, S., Yin, Z. \& Zhu, M. 2014. Diversity and species abundance patterns of the early Cambrian (Series 2, Stage 3) Chengjiang biota from China. Paleobiology, 40, 50-69.

ZhaO, Y. L., QIAN, Y. \& LI, X. S. 1994. Wiwaxia from Early-Middle Cambrian Kaili Formation in Taijiang, Guizhou. Acta Palaeontologica Sinica 33, 359-66 [in Chinese with English abstract].

ZhaO, Y. L., Yuan, J. L., Zhu, M. Y., Guo, Q. J., Zhou, Z., YANG, R. D. \& VAn Iten, H. 1999. The Early Cambrian Taijiang Biota of Taijiang, Guizhou, PRC. Acta Palaeontologica Sinica 38 (suppl), 108-15 [in Chinese with English abstract].

Zhu, M. Y., Li, G. X., Zhang, J. M., Steiner, M., Qian, Y. \& JianG, Z. W. 2001. Early Cambrian stratigraphy of east Yunnan, southwestern China: a synthesis. Acta Palaeontologica Sinica 40, 4-39.

ZhU, M.-Y., BAвCOCK, L. E. \& Steiner, M. 2005. Fossilization modes in the Chengjiang Lagerstätte (Cambrian of China): testing the roles of organic preservation and diagenetic alteration in exceptional preservation. Palaeogeography, Palaeoclimatology, Palaeoecology, 220, 31-46. 
Page 15 of 17

Proof For Review
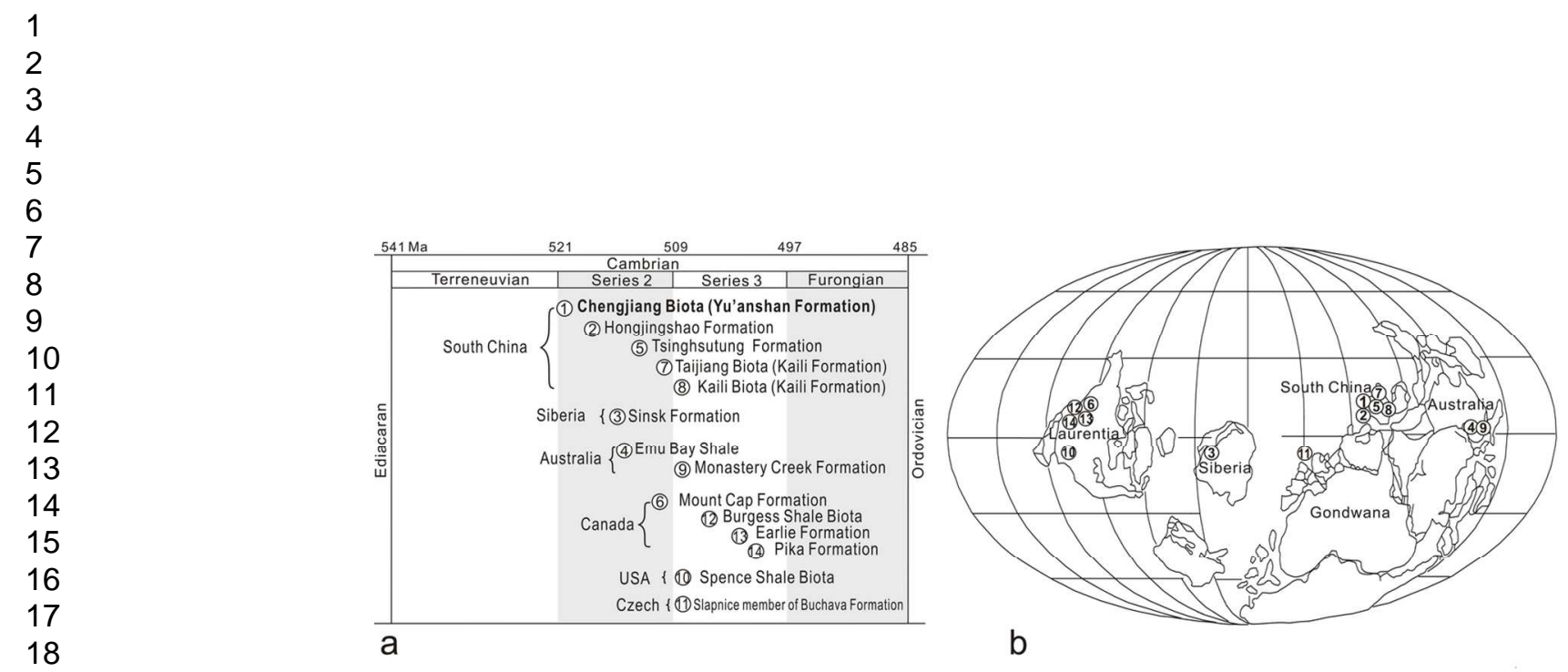

19

20

21

22

23

Figure 1. Distribution of Wiwaxia. (a) Stratigraphic distribution. (b) Palaeogeographic distribution (modified after McKerrow et al. 1992; Álvaro et al. 2003; Fatka et al. 2011). Numbers in (a) correspond to those plotted in (b).

24

25

26

27

28

29

30

31

32

33

34

35

36

37

38

39

40

41

42

43

44

45

46

47

48

49

50

51

52

53

54

55

56

57

58

59

60 $63 \times 23 \mathrm{~mm}(600 \times 600 \mathrm{DPI})$ 
Figure 2. Sclerites of Wiwaxia. (a-d) from the lower Cambrian (Series 2, Stage 3) Maotianshan Shale Member, Yu'anshan Formation (Eoredlichia-Wudingaspis Zone) in the Mafang section, Haikou near Kunming, Yunnan Province; (e) from the middle Cambrian (Series 3, Stage 5) Burgess Shale. (a) Part (NIGPAS160801a). (b) Enlargement of boxed area, showing tips of constituent sclerites in third bundle. (c) Counterpart (NIGPAS160801b). (d) Interpretative sketch of counterpart. (e) Semi-articulated scleritome from the Burgess Shale (Royal Ontario Museum 56965) illustrating variation in morphology between sclerite zones and splayed habit of upper lateral sclerite zone. $234 \times 707 \mathrm{~mm}$ (600 x 600 DPI) 


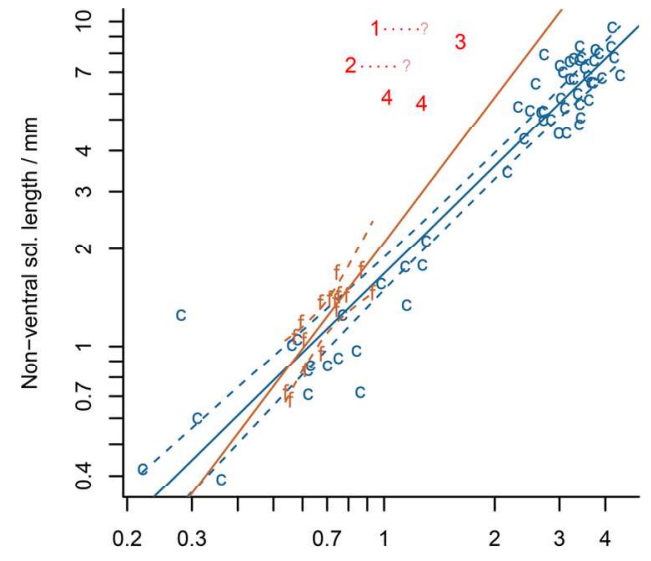

a

Non-ventral scl. width / $\mathrm{mm}$

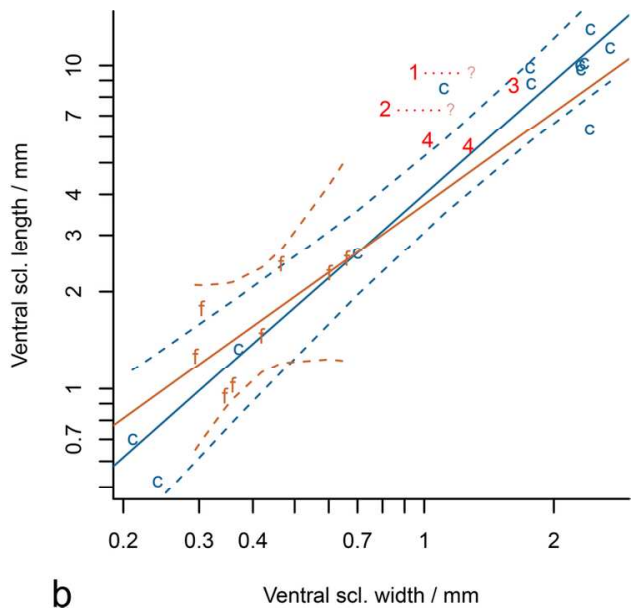

Figure 3. Comparison of sclerites from Chengjiang with those of other Wiwaxia species. Aspect ratio of sclerites in first (1), second (2), third (3) and fourth (4) sclerite bundles in NIGPAS160801 compared to non-ventral (a) and ventral (b) sclerites of Wiwaxia corrugata ( $c$, blue) and W. foliosa ( , orange). Width measurements from NIGPAS160801 may represent underestimates due to oblique preservation (see text). $76 \times 35 \mathrm{~mm}(600 \times 600 \mathrm{DPI})$ 